\title{
Molecular Phenotypes of Kidney Graft Rejection
}

\author{
Petra Hribova ${ }^{a}$ Ondrej Viklicky ${ }^{a, b}$ \\ ${ }^{a}$ Transplant Laboratory and b ${ }^{b}$ epartment of Nephrology, Institute for Clinical and Experimental Medicine, \\ Prague, Czech Republic
}

\section{Key Words}

Renal transplantation - Acute rejection - Gene expression • Molecular phenotype

\begin{abstract}
In the last decade, gene expression studies of kidney transplants provided an opportunity to better understand the development and regulation of kidney graft rejection. This review outlines the progress in the definition of biomarkers of rejection and, above all, concentrates on studies of the molecular phenotype of rejection. This phenotype, rather than morphological characterization, may be critical for assessing the ongoing processes in the graft and for the outcome prediction.

Copyright ๑ 2011 S. Karger AG, Basel
\end{abstract}

\section{Introduction}

Despite advances in immunosuppression, the longterm kidney allograft survival has not improved substantially. The main cause of graft loss in the long term remains to be chronic rejection, an entity challenged in the past, yet still contained in the Banff classification [1]. In the pathogenesis of this process, both cellular and humoral immune responses have been implicated. Standard therapy of chronic rejection has not been defined to date mainly because of late diagnosis. Deterioration of kidney graft function determined by the increase of serum creatinine frequently reflects the already developed and untreatable structural changes; however, molecular signatures of processes leading to those changes might be detected weeks before. To detect molecular fingerprints of developing injury, the identification of new noninvasive biomarkers of rejection and evaluation of intrarenal molecular events within the kidney graft in various clinical situations seem to be mandatory.

Diseases with similar morphological findings differ in their molecular patterns and this phenotype may be critical for assessing the risk of progression. Although initial knowledge comes from oncology [2], there are reports suggesting the progression of kidney diseases to be related with the intrarenal molecular phenotype [3, 4]. Recently, it has been hypothesized that molecular phenotypes of graft injury may predict the graft prognosis more accurately than the histology itself.

\section{Animal Lessons}

To understand the molecular processes of kidney graft rejection, various animal models have been studied. On the well-defined rat kidney transplantation model, Edemir et al. [5] demonstrated global changes in gene expression levels after syngeneic and allogeneic transplantation. Using DNA microarrays and qRT-PCR, they identified major immune effector-related pathways activated

\section{KARGER \\ Fax +4161306 1234 \\ E-Mail karger@karger.ch}

www.karger.com
(C) 2011 S. Karger AG, Basel

$1420-4096 / 11 / 0344-0291 \$ 38.00 / 0$

Accessible online at: www.karger.com/kbr
Prof. Ondrej Viklicky, MD, PhD

Department of Nephrology, Institute for Clinical and Experimental Medicine Videnska 1958/9

CZ-140 21 Prague 4 (Czech Republic)

Tel.+42026136 4106, E-Mail ondrej.viklicky@ikem.cz 
after allogeneic transplantation and related to acute rejection mechanism of tissue injury (e.g. Ifng, Tnf, Cxcl9, Xcl1, Cxcl10, Ccl3, Ccr1, Ccr2, Ccr5, Cd8a, Fcnb, Gzmb, Gzma, Prf, Cd3d, Cd8, and Cd163 were upregulated). In parallel, they identified a number of upregulated genes linked to tissue-protective and immune counterregulation mechanisms that would balance and limit the ongoing inflammatory/immune responses (e.g. C4bpa, Il10, Bcl2a1, Socs1, Il1rn, Hmox1). These observations fit with the evolving view of immunity as a balance between effector and regulatory mechanisms. An experimental system to classify transcripts as members of pathogenesisbased sets representing biological processes in injured or diseased tissue was used by Halloran et al. [6] in their microarray studies on mouse kidney transplants. Both isografts and allografts displayed host macrophage infiltration of interstitium from day 2 , followed by active injuryrepair response, with inflammatory features, injury-up features and loss of epithelial features. The allografts displayed specific expression of IFNG effects and T cell transcripts. Strong 'classical' (IFNG-induced) and alternative macrophage activation features coexisted in allografts. Transcripts associated with alternative macrophage activation were prominent in acute T-cell-mediated rejection (TCMR) and were also associated with tissue remodeling [7]. The injury-repair response in TCMR required T cells but was independent of $\mathrm{T}$ cell cytotoxic mechanisms, B cells and antibody [8]. Some of the cytotoxic T cell transcripts, e.g. Gzmb, Prf and Fas ligand previously described as specific for rejection $[9,10]$, were shown not to be specific for TCMR, because they also reflect homing of effector memory $\mathrm{T}$ cells to injured tissues, or natural killer cells in capillaries in acute antibody-mediated rejection (AMR) [6]. Several molecules associated with graft acceptance and rejection were described using the model of rat kidney and mouse heart transplantation [11]. The long-term acceptance of graft was shown to be associated with the high levels of Toag-1 and $\alpha$-1,2-mannosidase genes both in the graft and in peripheral blood, whereas their expression was downregulated in the peripheral blood 3-5 days before acute rejection of mouse heart and rat kidney allografts.

\section{Human Kidney Graft Biopsies}

\section{'0-Hour' Biopsies}

Interestingly, evaluation of ' 0 -hour' biopsies may detect molecular phenotypes associated with the risk of late graft dysfunction. It was shown that the transcriptome reflects kidney quality and susceptibility to delayed graft function better than available clinical and histopathological scoring systems [12]. The expression of TNFA, TGFB, CD25, and ICAM1 in '0-hour' biopsy predicted increased risk of delayed graft function and acute rejection and using these molecular markers together with clinical indicators further enhances the quality of prognosis [13]. Predictive models were built for proteinuria and graft loss 2 years after transplantation using clinical variables in combination with intragraft gene expression data [14]. Another study analyzed microarray gene expression in relation to histologic parameters of donor organs. In already injured kidney, the genes related to immunity and defense, cell communication and apoptosis were upregulated. Combination of histology with 3 from the set of differentially expressed genes (NLRP2, IGJ, and RGS5) increased the predictability of 1-year serum creatinine dramatically [15].

\section{'Case Biopsies'}

Earlier studies showed upregulation of Fas ligand mRNA in biopsy samples with therapy-resistant acute rejections versus samples with therapy-sensitive acute rejection $[16,17]$. Besides the upregulation of granulysin, higher intrarenal mRNA expression of NKG2D, which is activating cytotoxicity receptor expressed by natural killer cells, was reported to be associated with the deteriorated renal function at 6 and 12 months after transplantation, mainly in grafts with acute rejection [18].

The first evidence, that early acute rejection after transplantation is not a homogeneous molecular entity, was given by Sarwal et al. [19]. On the basis of hierarchical clustering, the 3 subtypes of acute rejection were defined. The subtypes of rejection differed in the expression of genes reflecting apoptosis, infiltration and activation of lymphocytes, driven by NFкB and interferon- $\gamma$, transcripts from T cells, natural killer cells, and macrophages. Enhanced expression of cytotoxic T lymphocyte effector genes (GZMA and RANTES), adhesion molecules, cytokines, cytokine receptors, and growth factors, and surprisingly also markers of B cells (CD20, CD74, immunoglobulin heavy and light chains, and other molecules associated with B cell receptors) was found in the subtype of acute rejection with the most unfavorable outcome. Acute rejection samples clustered with samples from patients with chronic allograft nephropathy showed enhanced expression of genes involved in cellular proliferation and cell cycling whereas the molecular features of lymphocyte infiltration and activation were minimal in this subtype. It suggests a relatively quiescent rejection process with active tissue repair and regeneration. 
Table 1. Molecular phenotypes in human kidney graft biopsies

\begin{tabular}{llll}
\hline & $\begin{array}{l}\text { Biopsies } \\
\mathrm{n}\end{array}$ & $\begin{array}{l}\text { Method used to } \\
\text { analyze expression }\end{array}$ & Main findings \\
\hline $\begin{array}{l}\text { '0-hour' biopsies } \\
\text { Mueller et al. }\end{array}$ & 87 & microarray & $\begin{array}{l}\text { Transcriptome of implant biopsies reflected kidney quality and susceptibility to } \\
\text { delayed allograft function better than clinical and histopathological scoring systems }\end{array}$ \\
\hline $\begin{array}{l}\text { Avihingsanon } 2008 \\
\text { et al. [13], 2005 }\end{array}$ & 75 & qRT-PCR & $\begin{array}{l}\text { TNFA, TGFB, CD25, and ICAM1 enhanced quality of prognosis from clinical } \\
\text { indicators }\end{array}$ \\
$\begin{array}{l}\text { Bodonyi- } \\
\text { Kovacs et al. }\end{array}$ & 73 & qRT-PCR & $\begin{array}{l}\text { High CD3 and low PECAM were associated with worse 2-year graft function; } \\
\text { high TNFA predicted worse 2-year graft survival }\end{array}$ \\
\hline 14], 2010 & 82 & microarray & $\begin{array}{l}\text { NLRP2, IGJ, and RGS5 combined with histology predicted 1-year serum } \\
\text { creatinine }\end{array}$ \\
$\begin{array}{l}\text { Perco et al. } \\
\text { 15], 2009 }\end{array}$ & &
\end{tabular}

\section{'Case biopsies'}

Nickel et al. $22(19) \quad$ qRT-PCR $\quad$ FASL was upregulated in therapy-resistant acute rejections

[16], 2001

\begin{tabular}{|c|c|c|c|}
\hline $\begin{array}{l}\text { Desvaux et al. } \\
{[17], 2004}\end{array}$ & 34 & qRT-PCR & FASL was a predictor of antirejection therapy resistance \\
\hline $\begin{array}{l}\text { Seiler et al. } \\
\text { [18], } 2007\end{array}$ & 109 & qRT-PCR & $\begin{array}{l}\text { NKG2D and granulysin upregulation was associated with restricted 6-month } \\
\text { graft outcome }\end{array}$ \\
\hline $\begin{array}{l}\text { Sarwal et al. } \\
{[19], 2003}\end{array}$ & $67(50)$ & microarray & $\begin{array}{l}\text { Immune activation and cellular proliferation-related gene expression pattern } \\
\text { distinguished subtypes of acute rejection with different outcome }\end{array}$ \\
\hline $\begin{array}{l}\text { Bagnasco et al. } \\
{[21], 2007}\end{array}$ & $74(58)$ & $\begin{array}{l}\text { immuno- } \\
\text { histochemistry }\end{array}$ & B-cell-rich infiltrates were not associated with worse outcome in acute rejection \\
\hline $\begin{array}{l}\text { Viklicky et al. } \\
{[22], 2010}\end{array}$ & 64 & qRT-PCR & $\begin{array}{l}\text { Low expression of CD } 20 \text { was associated with poor graft prognosis after early } \\
\text { acute rejection }\end{array}$ \\
\hline $\begin{array}{l}\text { Bestard et al. } \\
{[26], 2008}\end{array}$ & 37 & $\begin{array}{l}\text { immuno- } \\
\text { histochemistry }\end{array}$ & $\begin{array}{l}\text { FoxP3+ Treg in subclinical rejection in the } 6 \text { th month predicted better graft } \\
\text { function } 2 \text { and } 3 \text { years after transplantation }\end{array}$ \\
\hline $\begin{array}{l}\text { Bunnag et al. } \\
{[27], 2008}\end{array}$ & $83(77)$ & $\begin{array}{l}\text { microarray } \\
\text { qRT-PCR }\end{array}$ & $\begin{array}{l}\text { FOXP3 was evaluated in rejection (both TCMR and AMR); no relationship } \\
\text { between FOXP3 or FOXP3/GZMB expression and future function }\end{array}$ \\
\hline $\begin{array}{l}\text { Anglicheau } \\
\text { et al. [28], } 2009\end{array}$ & $33(32)$ & qRT-PCR & Evaluated the set of miRNAs predictive of acute rejection and allograft function \\
\hline \multicolumn{4}{|c|}{ ‘Protocol biopsies’ } \\
\hline $\begin{array}{l}\text { Mengel et al. } \\
{[30], 2010}\end{array}$ & 107 & microarray & $\begin{array}{l}\text { No association of gene expressions in 6-week protocol biopsies with future } \\
\text { rejection episodes, functional deterioration or allograft loss; early protocol } \\
\text { biopsies reflect more injury-repair response to implantation stresses }\end{array}$ \\
\hline
\end{tabular}


Table 1 (continued)

\begin{tabular}{|c|c|c|c|}
\hline & $\begin{array}{l}\text { Biopsies } \\
\mathrm{n}\end{array}$ & $\begin{array}{l}\text { Method used to } \\
\text { analyze expression }\end{array}$ & Main findings \\
\hline $\begin{array}{l}\text { Scherer et al. } \\
{[32], 2003}\end{array}$ & 17 & $\begin{array}{l}\text { microarray } \\
\text { qRT-PCR }\end{array}$ & $\begin{array}{l}\text { Ten genes were differentially expressed in } 6 \text {-month protocol biopsies in patients } \\
\text { developing chronic rejection within the following } 6 \text { months compared with } \\
\text { patients who remained stable }\end{array}$ \\
\hline $\begin{array}{l}\text { Park et al. } \\
{[33], 2010}\end{array}$ & 151 & $\begin{array}{l}\text { microarray } \\
\text { qRT-PCR }\end{array}$ & $\begin{array}{l}\text { The combination of fibrosis and inflammation (IFNG, UBD, CXCL9, CXCL10, } \\
\text { CD14, FOXP3 upregulation) in 1-year protocol biopsies was associated with } \\
\text { reduced graft function and survival }\end{array}$ \\
\hline $\begin{array}{l}\text { 'Late biopsies' } \\
\text { Pribylova- } \\
\text { Hribova et al. } \\
{[34], 2006}\end{array}$ & 174 & qRT-PCR & $\begin{array}{l}\text { TGFB1 mRNA upregulation in chronic allograft nephropathy predicted poor } \\
\text { renal graft function within the } 18 \text {-month follow-up }\end{array}$ \\
\hline $\begin{array}{l}\text { Famulski et al. } \\
{[37], 2010}\end{array}$ & $234(173)$ & $\begin{array}{l}\text { microarray } \\
\text { qRT-PCR }\end{array}$ & $\begin{array}{l}\text { The canonical form of TCMR in late biopsies was defined on the basis of molec- } \\
\text { ular phenotype and independent of histopathology with AMATs and GRITs as } \\
\text { the main feature and with the best prognosis despite severe inflammation }\end{array}$ \\
\hline $\begin{array}{l}\text { Sis et al. } \\
{[40], 2009}\end{array}$ & $212 / 169$ & microarray & $\begin{array}{l}\text { High endothelial-associated transcript expression with antibody predicts graft } \\
\text { loss in AMR patients better than C4d }\end{array}$ \\
\hline
\end{tabular}

Figures in parentheses indicate number of patients.

a Training set. ${ }^{b}$ Test set. ${ }^{c}$ Taqman low-density array.

The role of intragraft B cells in renal transplantation is the subject of many studies with controversial results. The $\mathrm{B}$ cell infiltrate during acute rejection was shown to be associated with poor prognosis in some $[19,20]$ but not all reports [21]. In early acute rejection, we showed several genes to be expressed differentially between AMR and TCMR and distinct molecular phenotypes were associated with poor kidney graft prognosis. Expression profiles suggesting lack of regulation defined as lower expression of FOXP3, TGFB1, RANTES and especially CD20, a marker of B cells, were observed within the graft that failed as a consequence of AMR [22]. What is the explanation of such differences in the published literature? The role of B cells turns out to be very complex and varied. Activated B cells are known to have the potential to serve as antigen-presenting cells, sustain $\mathrm{T}$ cell response in the graft and they may be related to more severe rejection outcome. B cells, however, may also play a role in transplantation tolerance, as indicated in recent reports from the ITN and RISET consortia [23]. Drug-free tolerant patients displayed increased numbers of $\mathrm{B}$ cells in peripheral blood, with a decreased memory pool and an increase in transitional and naïve B cell subsets. Enhanced expression of $\mathrm{B}$ cell differentiation and activation genes in tolerant patients was also reported [24]. The current view on the role of $\mathrm{B}$ cells in kidney graft rejection as well as in graft tolerance was reviewed by Zarkhin et al. [25].

A role of regulatory $\mathrm{T}$ cells in acute rejection is widely discussed as well. We showed a low FOXP3 intrarenal transcript to be associated with poor outcome of early antibody-mediated rejection [22]. Similarly, it was shown that the presence of FoxP3+ Treg in subclinical rejection in the 6th month predicts better graft function 2 and 3 years after transplantation [26]. Although the expression of FOXP3 in transplant biopsies is studied due to its role in a population of regulatory $\mathrm{T}$ cells, Bunnag et al. [27] 
showed evaluated expression of FOXP3 in rejection (both TCMR and AMR). They observed no relationship between the levels of FOXP3 or FOXP3/GZMB expression and future function.

Another enhanced step in studying gene expression is the focus on microRNAs (miRNAs). miRNAs are small, highly conserved RNA molecules acting as posttranscriptional regulators, and so controlling gene expression. Anglicheau et al. [28] reported that a number of tubular epithelial cell miRNAs are underexpressed during acute cellular rejection, while others are overexpressed, probably reflecting the graft infiltration by immune cells. They evaluated the set of miRNAs predictive of acute rejection and allograft function. miRNAs have also been reported to play a role in the regulation of the fibrosis process including epithelial-to-mesenchymal transition, so they also influence later states of renal allografts [29].

\section{'Protocol Biopsies'}

The question is, in general, whether a distinct molecular phenotype defined as upregulation of specific mRNA clusters may predict graft prognosis better than routine histology itself. Mengel et al. [30], in a larger study of 6 weeks' protocol biopsies early after transplantation, did not find any association of gene expressions with future rejection episodes, functional deterioration or allograft loss. The authors concluded that early protocol biopsies reflect more injury-repair response to implantation stresses and have little relationship to graft outcome. Recently, by analyzing the intrarenal expression of 9 genes (cytokines, chemokines, markers of $\mathrm{T} / \mathrm{B} /$ plasma cell infiltration) in 163 protocol biopsies at 12 weeks, we showed the high expression of chemokines RANTES and IP-10 in subclinical rejection including borderline changes to be associated with the higher risk of premature graft loss [31]. Clearly, this study was small and thus should be considered as preliminary and validation studies in larger cohorts are necessary. Scherer et al. [32] analyzed microarray expression profiles in 6 -month protocol biopsies, in order to determine genes predictive of chronic rejection development 12 months after kidney transplantation. Up to now, they have identified 10 genes differentially expressed in patients developing chronic rejection within the following 6 months compared to patients who remained stable during follow-up. Such data support the hypothesis that changes in gene expression patterns in the transplanted kidney graft may be detected early prior to the apparent clinical and histological manifestation of chronic rejection. Moreover, kidney graft recipients with normal morphology or only interstitial fibrosis and tubu- lar atrophy and without inflammation in 12-month protocol biopsies showed significantly better survival than patients with interstitial fibrosis and tubular atrophy together with subclinical inflammation. The combination of fibrosis and inflammation was associated with increased activity of innate immune pathways including IFNG and TLR responses as well as increased T cell immunity (IFNG, UBD, CXCL9, CXCL10, CD14, FOXP3) and downregulation of protective gene products (TOLLIP, VEGF, BCL2) [33].

\section{'Late Biopsies'}

TGFB1 was shown to be upregulated in both acute and chronic rejection of kidney allograft. The expression of TGFB1 during acute and chronic rejection and its relation to transplant outcome was reported [34] by our group. We demonstrated no association of TGFB1 mRNA levels with the short-term acute rejection outcome, but TGFB1 mRNA upregulation in chronic allograft nephropathy predicted poor renal graft function within the 18-month follow-up. This might indicate the importance of the fibrosis phenotype in late-stage kidney grafts. Similarly, higher expression of intrarenal proinflammatory genes in biopsies with chronic allograft nephropathy was shown to be able to discriminate patients at a higher risk for earlier allograft failure. Kaplan-Meier survival analysis revealed that proteinuria and higher expression of TGFB1 and MCP1 in transplant patients with chronic allograft nephropathy were a prognostic of poor graft outcome. This suggests that unfavorable outcome depends on tissue remodeling and fibrosis together with active immune processes in late biopsy samples [35].

This hypothesis was confirmed by a large study of Einecke et al. [36]. They analyzed gene expression in 105 for-cause biopsies using microarrays to identify genes associated with graft loss and developed the molecular risk scores strongly associated with graft loss. They found that the transcripts predicting graft failure were those reflecting tissue injury (e.g. ITGB6, HAVCR1, LTF, ADAMTS1, SERPINA3, MMP7, C3, COL1A2), dedifferentiation and epithelial-to-mesenchymal transition (NNMT, VCAN), and tissue remodeling, but not those reflecting inflammation (IFNG effects and T cell or macrophage infiltration). Risk predictions were accurate when applied to the late biopsy population. It indicates that the active ongoing tissue response to injury is the final common pathway linking mechanisms of inflammation and noninflammatory disease states to parenchymal loss, dysfunction and kidney failure. Similarly, in progressive but not in stable proteinuric disease, proximal 
tubular epithelial cells showed elevated expression of genes of intracellular hypoxia response and VEGF signaling pathways (e.g. CREBBP, PTK2B, NOS1, MAPK1, HIF1A) [3]. Famulski et al. [37] defined the canonical form of TCMR (CTCMR) in late biopsies on the basis of molecular phenotype and independent of histopathology. The molecular features of cTCMR were expression of alternative macrophage activation transcripts (AMAT1) and high levels of IFNG-induced transcripts (GRIT1). The cTCMR biopsies were the most severely inflamed, but surprisingly had the best prognosis. The importance of molecular phenotype can be further illustrated on chronic AMR. Although the diagnosis of AMR is based on the presence of circulating donor-specific antibodies, histopathologic evidence of tissue injury and C4d-positive staining [1], there is recent evidence that some type of chronic AMR can occur without C4d+ [38, 39]. AMR is dominated by endothelial damage in microcirculation. Endothelial-associated transcripts identified from the literature were reported to be upregulated in both, C4dnegative and C4d-positive forms of AMR. Moreover, high endothelial-associated transcript expression with alloantibody predicted poor kidney graft outcome and graft loss better than C4d [40].

\section{Noninvasive Markers of Graft Prognosis}

When searching for noninvasive methods to find biomarkers in renal transplantation, urine seems to be the optimal fluid for investigation of different intragraft processes. Earlier studies showed urine levels of mRNAs for PRF and GZMB to be associated with and even predictive of acute rejection. Muthukumar et al. [41] analyzed transcripts from urine sediment and found FOXP3, CD25, CD3E, and PRF mRNA in 36 renal allograft recipients with acute rejection, 18 subjects with chronic allograft nephropathy and 29 subject with normal biopsy results. They found expression levels of all investigated genes to be upregulated in acute rejection as compared with chronic allograft nephropathy or normal biopsies, but only FOXP3 mRNA urinary levels were predictive of the acute rejection outcome or graft failure. Matz et al. [42] showed IP-10 expression in urine to identify patients with ongoing acute rejection episodes several days before serum creatinine elevation and biopsy indication. Elevated levels of IP-10 protein within the first 4 posttransplant weeks were predictive of restricted graft function at 6 months even in the absence of acute rejection. Finally, Afaneh et al. [43] reported that acute rejection could be predicted by the urinary levels of mRNA for OX40, OX40L, PD-1, and FOXP3. The acute rejection reversibility was predicted by the levels of mRNA for OX40, OX40L, and FOXP3, whereas only OX40 mRNA levels predicted graft loss after acute rejection.

Besides the studies of mRNA expression in urinary cells, urine proteomics becomes an important field in the study of markers of renal graft dysfunction. Although several studies identified a 'rejection pattern' that is able to discriminate samples with acute rejection from samples with stable graft function [44, 45], the influence of immunosuppressive drugs and possible infections on the urine proteome remains to be discussed [46]. Also differences in urinary polypeptide patterns related to chronic allograft dysfunction have been identified recently. O'Riordian et al. [47] found several urinary proteins that are associated with chronic allograft nephropathy. Following the latest Banff classification, Quintana et al. [48] showed that the composition of the proteome differs between interstitial fibrosis and tubular atrophy and chronic active AMR.

\section{Conclusion}

Molecular biomarkers are much more specific than routine laboratory tests used for graft monitoring and can discriminate between different mechanisms of injury. Analyzing the role of distinct molecular phenotypes of kidney graft diseases using molecular pathology methods may help to better define patients at risk that need early or different intervention. On the other hand, such techniques may identify patients in whom the alloimmune response has been silenced and who do not need more than minimal immunosuppression.

\section{Acknowledgements}

This work was supported by grants from the Czech Ministry of Health, Grant Agency of the Czech Republic and the Institute for Clinical and Experimental Medicine: NR/8913-4/2006, NR/9388-3/2007, NS10516-3/2009, NS10517-3/2009, NT112275/2010, P301/11/1568, and MZO 00023001. 


\section{References}

1 Solez K, Colvin RB, Racusen LC, Haas M, Sis B, Mengel M, Halloran PF, Baldwin W, Banfi G, Collins AB, et al: Banff 07 classification of renal allograft pathology: updates and future directions. Am J Transplant 2008;8: 753-760.

-2 Misra RR, Pinsky PF, Srivastava S: Prognostic factors for hematologic cancers. Hematol Oncol Clin North Am 2000;14:907-924.

$\checkmark 3$ Rudnicki M, Perco P, Enrich J, Eder S, Heininger D, Bernthaler A, Wiesinger M, Sarkozi R, Noppert SJ, Schramek H, et al: Hypoxia response and VEGF-A expression in human proximal tubular epithelial cells in stable and progressive renal disease. Lab Invest 2009;89:337-346.

4 Brabcova I, Tesar V, Honsova E, Lodererova A, Novotna E, Maixnerova D, Merta M, Burgelova M, Hribova P, Skibova J, et al: Association of advanced vasculopathy and transforming growth factor-betal gene expression with immunoglobulin A nephropathy progression. Nephrol Dial Transplant 2011;26:573-579.

$>5$ Edemir B, Kurian SM, Eisenacher M, Lang D, Muller-Tidow C, Gabriels G, Salomon DR, Schlatter E: Activation of counter-regulatory mechanisms in a rat renal acute rejection model. BMC Genomics 2008;9:71.

$\checkmark 6$ Halloran PF, de Freitas DG, Einecke G, Famulski KS, Hidalgo LG, Mengel M, Reeve J, Sellares J, Sis B: The molecular phenotype of kidney transplants. Am J Transplant 2010; 10:2215-2222.

$>7$ Famulski KS, Sis B, Billesberger L, Halloran PF: Interferon-gamma and donor MHC class I control alternative macrophage activation and activin expression in rejecting kidney allografts: a shift in the Th1-Th2 paradigm. Am J Transplant 2008;8:547-556.

>8 Famulski KS, Broderick G, Einecke G, Hay K, Cruz J, Sis B, Mengel M, Halloran PF: Transcriptome analysis reveals heterogeneity in the injury response of kidney transplants. Am J Transplant 2007;7:2483-2495.

$>9$ Hoffmann SC, Hale DA, Kleiner DE, Mannon RB, Kampen RL, Jacobson LM, Cendales LC, Swanson SJ, Becker BN, Kirk AD: Functionally significant renal allograft rejection is defined by transcriptional criteria. Am J Transplant 2005;5:573-581.

$\checkmark 10$ Li B, Hartono C, Ding R, Sharma VK, Ramaswamy R, Qian B, Serur D, Mouradian J, Schwartz JE, Suthanthiran M: Noninvasive diagnosis of renal-allograft rejection by measurement of messenger RNA for perforin and granzyme B in urine. $\mathrm{N}$ Engl J Med 2001;344:947-954.

11 Sawitzki B, Bushell A, Steger U, Jones N, Risch K, Siepert A, Lehmann M, SchmittKnosalla I, Vogt K, Gebuhr I, et al: Identification of gene markers for the prediction of allograft rejection or permanent acceptance. Am J Transplant 2007;7:1091-1102.
12 Mueller TF, Reeve J, Jhangri GS, Mengel M, Jacaj Z, Cairo L, Obeidat M, Todd G, Moore R, Famulski KS, et al: The transcriptome of the implant biopsy identifies donor kidneys at increased risk of delayed graft function. Am J Transplant 2008;8:78-85.

13 Avihingsanon Y, Ma N, Pavlakis M, Chon WJ, Uknis ME, Monaco AP, Ferran C, Stillman I, Schachter AD, Mottley C, et al: On the intraoperative molecular status of renal allografts after vascular reperfusion and clinical outcomes. J Am Soc Nephrol 2005; 16: 1542-1548.

14 Bodonyi-Kovacs G, Putheti P, Marino M, Avihingsanon Y, Uknis ME, Monaco AP, Strom TB, Pavlakis M: Gene expression profiling of the donor kidney at the time of transplantation predicts clinical outcomes 2 years after transplantation. Hum Immunol 2010;71:451-455.

15 Perco P, Kainz A, Wilflingseder J, Soleiman A, Mayer B, Oberbauer R: Histogenomics: association of gene expression patterns with histological parameters in kidney biopsies. Transplantation 2009;87:290-295.

16 Nickel P, Lacha J, Ode-Hakim S, Sawitzki B, Babel N, Frei U, Volk HD, Reinke P: Cytotoxic effector molecule gene expression in acute renal allograft rejection: correlation with clinical outcome; histopathology and function of the allograft. Transplantation 2001;72:1158-1160.

-17 Desvaux D, Schwarzinger M, Pastural M, Baron C, Abtahi M, Berrehar F, Lim A, Lang $\mathrm{P}$, le Gouvello S: Molecular diagnosis of renal-allograft rejection: correlation with histopathologic evaluation and antirejectiontherapy resistance. Transplantation 2004;78: 647-653.

18 Seiler M, Brabcova I, Viklicky O, Hribova P, Rosenberger C, Pratschke J, Lodererova A, Matz M, Schonemann C, Reinke P, et al: Heightened expression of the cytotoxicity receptor NKG2D correlates with acute and chronic nephropathy after kidney transplantation. Am J Transplant 2007;7:423-433.

19 Sarwal M, Chua MS, Kambham N, Hsieh SC, Satterwhite T, Masek M, Salvatierra O Jr: Molecular heterogeneity in acute renal allograft rejection identified by DNA microarray profiling. N Engl J Med 2003;349:125138.

20 Tsai EW, Rianthavorn P, Gjertson DW, Wallace WD, Reed EF, Ettenger RB: CD20+ lymphocytes in renal allografts are associated with poor graft survival in pediatric patients. Transplantation 2006;82:1769-1773.

21 Bagnasco SM, Tsai W, Rahman MH, Kraus ES, Barisoni L, Vega R, Racusen LC, Haas M, Mohammed BS, Zachary AA, Montgomery RA: CD20-positive infiltrates in renal allograft biopsies with acute cellular rejection are not associated with worse graft survival. Am J Transplant 2007;7:1968-1973.
22 Viklicky O, Hribova P, Volk HD, Slatinska J, Petrasek J, Bandur S, Honsova E, Reinke P: Molecular phenotypes of acute rejection predict kidney graft prognosis. J Am Soc Nephrol 2010;21:173-180.

23 Sagoo P, Perucha E, Sawitzki B, Tomiuk S, Stephens DA, Miqueu P, Chapman S, Craciun L, Sergeant R, Brouard S, et al: Development of a cross-platform biomarker signature to detect renal transplant tolerance in humans. J Clin Invest 2010;120:1848-1861.

24 Newell KA, Asare A, Kirk AD, Gisler TD, Bourcier K, Suthanthiran M, Burlingham WJ, Marks WH, Sanz I, Lechler RI, et al: Identification of a B cell signature associated with renal transplant tolerance in humans. J Clin Invest 2010;120:1836-1847.

25 Zarkhin V, Chalasani G, Sarwal MM: The yin and yang of $\mathrm{B}$ cells in graft rejection and tolerance. Transplant Rev (Orlando) 2010; 24:67-78.

26 Bestard O, Cruzado JM, Rama I, Torras J, Goma M, Seron D, Moreso F, Gil-Vernet S, Grinyo JM: Presence of FoxP3+ regulatory T cells predicts outcome of subclinical rejection of renal allografts. J Am Soc Nephrol 2008;19:2020-2026.

27 Bunnag S, Allanach K, Jhangri GS, Sis B, Einecke G, Mengel M, Mueller TF, Halloran PF: FOXP3 expression in human kidney transplant biopsies is associated with rejection and time post transplant but not with favorable outcomes. Am J Transplant 2008;8: 1423-1433.

28 Anglicheau D, Sharma VK, Ding R, Hummel A, Snopkowski C, Dadhania D, Seshan SV, Suthanthiran M: MicroRNA expression profiles predictive of human renal allograft status. Proc Natl Acad Sci USA 2009; 106:53305335.

29 Anglicheau D, Muthukumar T, Suthanthiran M: MicroRNAs: small RNAs with big effects. Transplantation 2010;90:105-112.

30 Mengel M, Chang J, Kayser D, Gwinner W, Schwarz A, Einecke G, Broecker V, Famulski K, De Freitas DG, Guembes-Hidalgo L, et al: The molecular phenotype of 6-week protocol biopsies from human renal allografts: reflections of prior injury but not future course. Am J Transplant 2010, E-pub ahead of print.

31 Matl I, Hribova P, Honsova E, Brabcova I, Viklicky O: Potential predictive markers in protocol biopsies for premature renal graft loss. Kidney Blood Press Res 2010;33:7-14.

-32 Scherer A, Krause A, Walker JR, Korn A, Niese D, Raulf F: Early prognosis of the development of renal chronic allograft rejection by gene expression profiling of human protocol biopsies. Transplantation 2003;75: 1323-1330.

33 Park WD, Griffin MD, Cornell LD, Cosio FG, Stegall MD: Fibrosis with inflammation at one year predicts transplant functional decline. J Am Soc Nephrol 2010;21:1987-1997. 
-34 Pribylova-Hribova P, Kotsch K, Lodererova A, Viklicky O, Vitko S, Volk HD, Lacha J: TGF-betal mRNA upregulation influences chronic renal allograft dysfunction. Kidney Int 2006;69:1872-1879.

35 Hribova P, Lacha J, Kotsch K, Volk HD, Brabcova I, Skibova J, Vitko S, Viklicky O: Intrarenal cytokine and chemokine gene expression and kidney graft outcome. Kidney Blood Press Res 2007;30:273-282.

-36 Einecke G, Reeve J, Sis B, Mengel M, Hidalgo L, Famulski KS, Matas A, Kasiske B, Kaplan B, Halloran PF: A molecular classifier for predicting future graft loss in late kidney transplant biopsies. J Clin Invest 2010;120: 1862-1872.

- 37 Famulski KS, Einecke G, Sis B, Mengel M, Hidalgo LG, Kaplan B, Halloran PF: Defining the canonical form of T-cell-mediated rejection in human kidney transplants. Am J Transplant 2010;10:810-820.

- 38 Sis B, Halloran PF: Endothelial transcripts uncover a previously unknown phenotype: C4d-negative antibody-mediated rejection. Curr Opin Organ Transplant 2010;15:42-48.
39 Sis B, Mengel M, Haas M, Colvin RB, Halloran PF, Racusen LC, Solez K, Baldwin WM 3rd, Bracamonte ER, Broecker V, et al: Banff '09 meeting report: antibody mediated graft deterioration and implementation of Banff working groups. Am J Transplant 2010;10: 464-471.

40 Sis B, Jhangri GS, Bunnag S, Allanach K, Kaplan B, Halloran PF: Endothelial gene expression in kidney transplants with alloantibody indicates antibody-mediated damage despite lack of C4d staining. Am J Transplant 2009;9:2312-2323.

41 Muthukumar T, Dadhania D, Ding R, Snopkowski C, Naqvi R, Lee JB, Hartono C, Li B, Sharma VK, Seshan SV, et al: Messenger RNA for FOXP3 in the urine of renal-allograft recipients. N Engl J Med 2005;353: 2342-2351.

42 Matz M, Beyer J, Wunsch D, Mashreghi MF, Seiler M, Pratschke J, Babel N, Volk HD, Reinke P, Kotsch K: Early post-transplant urinary IP-10 expression after kidney transplantation is predictive of short- and longterm graft function. Kidney Int 2006;69: 1683-1690.

43 Afaneh C, Muthukumar T, Lubetzky M, Ding R, Snopkowski C, Sharma VK, Seshan S, Dadhania D, Schwartz JE, Suthanthiran M: Urinary cell levels of mRNA for OX40, OX40L, PD-1, PD-L1, or PD-L2 and acute rejection of human renal allografts. Transplantation 2010;90:1381-1387.
44 O’Riordan E, Orlova TN, Mei JJ, Butt K, Chander PM, Rahman S, Mya M, Hu R, Momin J, Eng EW, et al: Bioinformatic analysis of the urine proteome of acute allograft rejection. J Am Soc Nephrol 2004;15:32403248.

- 45 Schaub S, Rush D, Wilkins J, Gibson IW, Weiler T, Sangster K, Nicolle L, Karpinski M, Jeffery J, Nickerson P: Proteomic-based detection of urine proteins associated with acute renal allograft rejection. J Am Soc Nephrol 2004;15:219-227.

46 Wittke S, Haubitz M, Walden M, Rohde F, Schwarz A, Mengel M, Mischak H, Haller H, Gwinner W: Detection of acute tubulointerstitial rejection by proteomic analysis of urinary samples in renal transplant recipients. Am J Transplant 2005;5:2479-2488.

47 O'Riordan E, Orlova TN, Mendelev N, Patschan D, Kemp R, Chander PN, Hu R, Hao G, Gross SS, Iozzo RV, et al: Urinary proteomic analysis of chronic allograft nephropathy. Proteomics Clin Appl 2008;2: 1025-1035.

48 Quintana LF, Sole-Gonzalez A, Kalko SG, Banon-Maneus E, Sole M, Diekmann F, Gutierrez-Dalmau A, Abian J, Campistol JM: Urine proteomics to detect biomarkers for chronic allograft dysfunction. J Am Soc Nephrol 2009;20:428-435. 